新長崎漁港における石炭灰コンクリート基板に対する付着生物調査

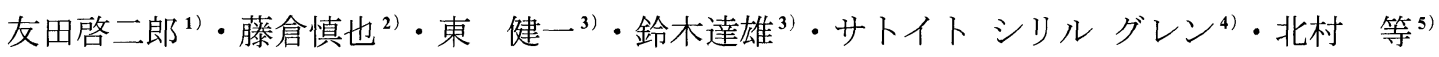

1) 東和科学株式会社 $=730-0841$ 広島県広島市中区舟入町6-5

2) 株式会社エヌ・イーサポート テ733-0812 広島県広島市西区己斐本町3-13-16

3) 株式会社アッシュクリート †151-0062＼cjkstart東京都渋谷区元代々木町30-13

4) 長崎大学生産科学研究科 $\bar{T} 852-8521$ 長崎市文教町1-14

${ }^{5)}$ 長崎大学水産学部 干852-8521 長崎市文教町1-14

\title{
Sessile organisms on coal-flyash concrete plates immersed in Shin-Nagasaki fishing port
}

\section{Keijirou Tomoda ${ }^{1)}$, Shinya Fuzikura ${ }^{2)}$, Kenichi Azuma ${ }^{3)}$, Tatsuo Suzuki ${ }^{3)}$, Cyril Glenn Satuito ${ }^{4)}$, and Hitoshi Kitamura $^{5)}$}

1) Towa Kagaku Co., Ltd., 6-5 Funairi-machi, Naka-ku, Hiroshima, 730-0841, Japan

2) Nature Environment Support Co., Ltd., 3-13-16 Koihon-machi, Nishi-ku, Hiroshima, 733-0812, Japan

3) Ashcrete Co., Ltd., 30-13 Motoyoyogi-cho, Shibuya-ku, Tokyo, 151-0062, Japan

4) Graduate School of Science and Technology, Nagasaki University, 1-14 Bunkyo-machi, Nagasaki, 852-8521, Japan

${ }^{5)}$ Faculty of Fisheries, Nagasaki University, 1-14, Bunkyo-machi, Nagasaki, 852-8521, Japan

Corresponding author: kei-tomoda@mail.towakagaku.co.jp

(Received March 19, 2007; Accepted July 8, 2007)

\begin{abstract}
Coal-flyash concrete and ordinary concrete plates were immersed in the sea near Shin-Nagasaki fishing port, Nagasaki, Japan, for different periods from October, 2004, to January, 2006. The marine sessile organisms that settled on these plates were studied. Throughout the study period, barnacles (Amphibalanus amphitrite, B. trigonus), bryozoans (Bugula neritina), ascidians (Styela plicata), some species of polychaetes, and algae were observed settling on both kinds of plate. Wet weights of organisms on the two types of plate were the same. These results indicate that coal-flyash concrete is suitable for use in constructing artificial fishing reefs, as a substitute for usual concrete.
\end{abstract}

キーワード : 新長崎漁港、石炭灰コンクリート、付着生物

沿岸漁業の振興策として、人工魚礁の造成が各地で盛 んに行われている。これら魚礁の主な材料として、従来 から石材、コンクリート、鋼材、プラスチックなどが用 いられてきたが、近年は古タイヤや廃船、または火山灰、 貝殼などの廃材なども利用されている（柿本、1998）。 廃棄物利用の一例として、石炭火力発電所から発生する 石炭灰を主材料としたコンクリート（石炭灰コンクリー トと呼ばれる、(社)マリノフォーラム21、1989）が魚礁
として使われている（(社)マリノフォーラム21、1997）。 ところで、魚礁に魚類等が集まる理由としては、これ ら魚類等に餌場、産卵場、生息場、逃避場などを提供す るためとされており、餌場の機能のひとつとして、人工 魚礁に着生する付着生物が重要と考えられている（(社） 全国沿岸漁業振興開発協会、2000)。石炭灰コンクリー 卜に対する付着生物調査は民間企業などで行われている が、学術的な報告例は無い。そこで本研究では、試験板 
調査法（梶原、1979）を用いて、石炭灰コンクリートに 対する付着生物の着生状況を調査した。

\section{調查方法}

付着生物調查は長崎県総合水産試験場の浮き栈橋で行 い（Fig. 1)、試験基板としては石炭灰コンクリート、 通常のコンクリート（以下、普通コンクリートとする）、 および試験板調查法で標準となる塩化ビニルの 3 種類と した。普通コンクリートの組成（重量％）は水が約 $7 \%$ 、 セメントが約 $12 \%$ 、他に細砂・砂利が約 $80 \%$ である。こ れに対して、石炭灰コンクリートはセメントが約 $10 \%$ 、 水が $20 \%$ 、残りの約70\%が石炭灰であり、普通コンクリー 卜と比べ軽い（約75\%）。なお、石炭灰からの重金属流 出が眯念されたが、本コンクリートは水産庁振興部開発 課長通達（1983）による安全基準を満足している（(社） マリノフォーラム21、1988)。

石炭灰コンクリート、普通コンクリート、塩化ビニル は、共に各々縦 $15 \mathrm{~cm}$ 、横 $15 \mathrm{~cm}$ 、厚さ $1 \mathrm{~cm}$ (両面で $450 \mathrm{~cm}^{2}$ ) であり、各重量は石炭灰コンクリート $390 \mathrm{~g}$ 、普通コンク リート530g、塩化ビニルが $330 \mathrm{~g}$ であった。これらを海面 下1. 5- $3 \mathrm{~m}$ に石炭灰コンクリート、普通コンクリート、 塩化ビニルの順にクレモナロープで垂下した。なお、こ れらの水深範囲であれば付着生物の種類や量に大きな差 がないことが経験的に知られている（北村、私信）。

垂下調查は2004年10月に開始し、2006年 1 月までの 15 ケ月間にわたって行った。この間、 1 ケ月間、 3 ケ月間、
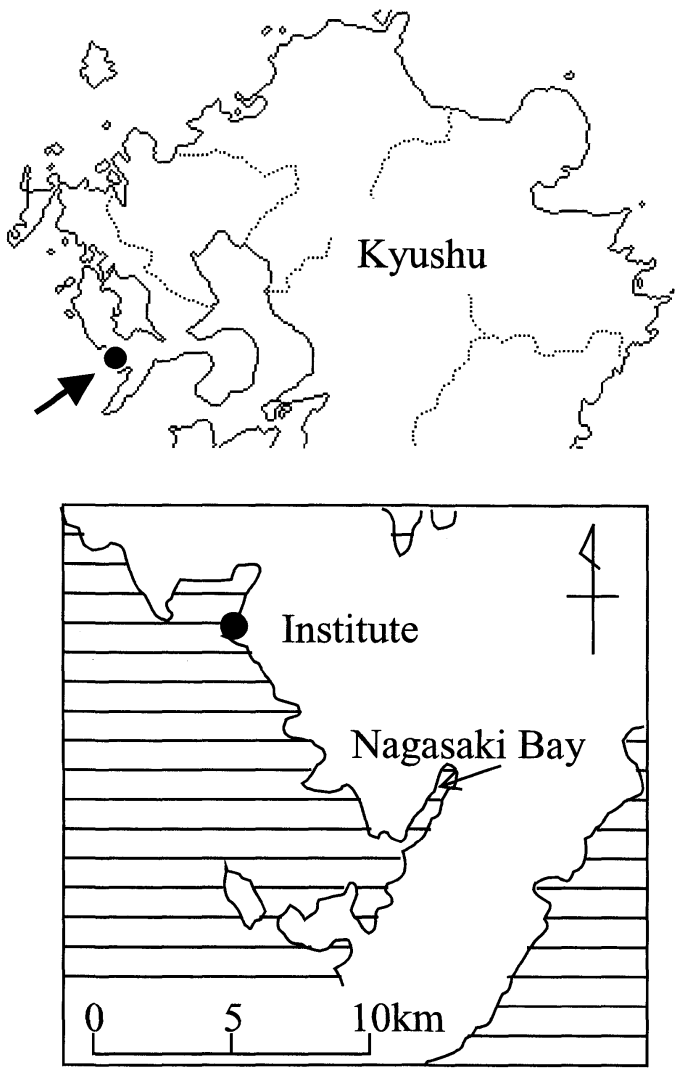

Fig. 1 Location of the experimental site (Nagasaki Prefectural Institute of Fisheries).
6 ケ月間、12ヶ月間および15ケ月閒の垂下を行った。す なわち 1 ケ月間の垂下では合計15回の垂下、取り上げを 行った。 3 ヶ月間垂下では、合計 5 回、同じく 6 ヶ月で は合計 2 回の取り上げを行った。12ヶ月基板および15ヶ 月基板は、先述のごとく、2004年10月に垂下し、各々 1 回の取り上げであった。

海域より回収した試験板については、遊在目のゴカイ やカニなどを取り除いた後、湿重量を測定した（風乾、 $2 \mathrm{~h}$ )。この重量から垂下前の重さ（濾過海水に垂下、そ の後、風乾、2 h）を差し引いて付着生物の湿重量を求 めた。付着生物の種類については、1 ケ月基板は両面に 付着した主な生物の種類および個体数（または群体数） を調べた。 3 -15ヶ月基板については、代表的な種を基 板より剥がし、各々の重量を測定した。なお、分類はフ ジツボ類、ホヤ類、コケムシ類のごとくグループ（付着 生物研究法、1986）別とした。このうち保存および分類 が比較的容易なフジツボ類については、種まで調べた。 これらの付着重量および付着数については、他の調査と 比較するために、単位 $\mathrm{m}^{2}$ あたりに換算した。なお、以 上の調査時には水温、透明度を測定した。

\section{結 果}

石炭灰コンクリート、普通コンクリートおよび塩化ビ ニルにおける 1 ケ月垂下、全15回の付着重量 $\left(\mathrm{g} / \mathrm{m}^{2}\right)$ の変化を水温と共にFig. 2 に示す。また出現した主な付 着動物の種類および個体数（単位 $\mathrm{m}^{2}$ ) をTable 1 に示す。 透明度については、海底が見える場合が多く、水深に相 当する $8 \mathrm{~m}$ 以上であった。

全15回の付着重量の推移（Fig. 2) では、石炭灰コン クリートおよび普通コンクリートは、ほぼ同様の重量、 および周年変化を示したが、塩化ビニルは全体的に付着 重量が低い結果となった。また、主な出現種類は 3 種基

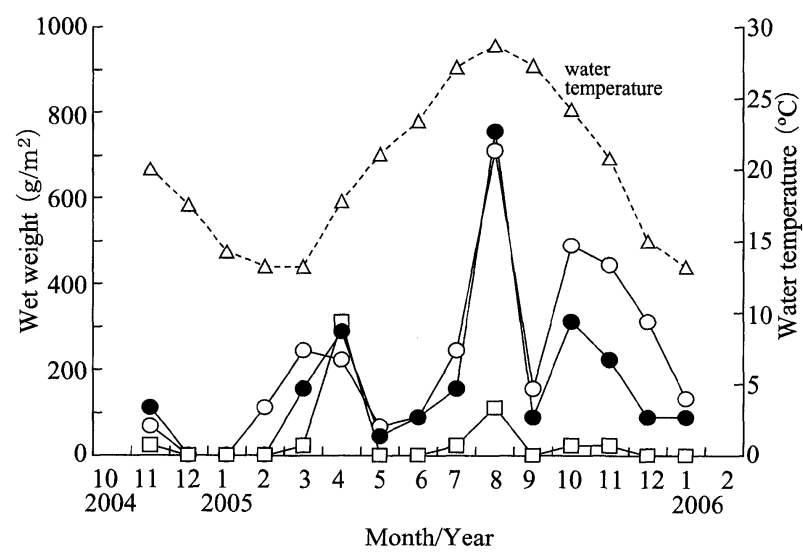

Fig. 2 Changes in water temperature and wet weight of fouling organisms on test plates submerged for one month at the pier of the Nagasaki Prefectural Institute of Fisheries in Shin-Nagasaki fishing port from October, 2004, to February, 2006.

O: Coal-flyash concrete plate,

Ordinary concrete plate, $\square$ : Polyvinyl chloride plate. 
板でほぼ同様であった（Table 1)。月別にみると、調査 開始の $11-2$ 月では 3 基板ともに、ほぼ $100 \mathrm{~g} / \mathrm{m}^{2}$ 以下 であったが、3-4月はアオサ類が付着し、その重量が $300 \mathrm{~g} / \mathrm{m}^{2}$ 前後となった。4-5月では海藻類が消失し $70 \mathrm{~g} / \mathrm{m}^{2}$ 以下となり、5-6月ではカンザシゴカイ類が 付着し、重量が若干増加した。7-8月にはフジツボ類 (タテジマフジツボ Amphibalanus amphitriteおよびサ ンカクフジツボ Balanus trigonus) が付着し、両コン クリート基板は共に $700 \mathrm{~g} / \mathrm{m}^{2}$ を超えた。 8 - 9 月はカ ンザシゴカイ類およびフジツボ類の付着が減少し、重量 は200 g/m²以下なった。しかし、9-10月は再び、 カンザシゴカイ類が付着し $300-500 \mathrm{~g} / \mathrm{m}^{2}$ となった。1011 月の 1 ケ月は前年（2004年）同期が $100 \mathrm{~g} / \mathrm{m}^{2}$ 前後で あったが、2005年では200-400 g/ $\mathrm{m}^{2}$ を示した。この違 いはアオサ類の付着量の違いであった。

垂下 3 ケ月間におけりる付着重量をFig. 3 に示す。合計 5 回の垂下、取り上げを行ったが、水温の低い時期に当 たる2004年10月 - 2005年 1 月、 $1-4$ 月および2005年 10 月 -2006 年 1 月では、全ての基板で付着重量はほぼ $1 \mathrm{~kg} / \mathrm{m}^{2}$ 以下となった。出現した種類も 3 種ともに同様 であり、フクロノリ（Colpomenia sinuosa）、アオサ類 などの海藻が占めていた。水温の上昇する $4-7$ 月の 3 ケ月では、フジッボ類、フサコケムシ (Bugula
neritina)、シロボヤ（Styela plicata）が多数付着し、 石炭灰コンクリートと普通コンクリートとの付着重量は 共に約 $4 \mathrm{~kg} / \mathrm{m}^{2}$ となったが、塩化ビニルは $2 \mathrm{~kg} / \mathrm{m}^{2}$ であっ た。 7-10月の 3 ケ月ではタテジマフジッボとサンカク フジッボが多数付着し、重量としてみるとフジッボ類の みとなった。石炭灰コンクリート、および普通コンクリー 卜は共に $12 \mathrm{~kg} / \mathrm{m}^{2}$ 前後となったが、塩化ビニルは約 $6 \mathrm{~kg}$ / $\mathrm{m}^{2}$ であった。

垂下 6 ケ月、12ヶ月および15ケ月の付着重量をFig. 4 に示寸。6 ケ月基板の付着重量は、水温の低い2004年 10 月 -2005 年 4 月では 3 種基板共に $1-4 \mathrm{~kg} / \mathrm{m}^{2}$ であった。 水温の高い $4-10$ 月の基板では石炭灰コンクリートが 23 $\mathrm{kg} / \mathrm{m}^{2}$ 、普通コンクリートが $16 \mathrm{~kg} / \mathrm{m}^{2}$ となり、石炭灰コ ンクリートが上回った。両者の差 $7 \mathrm{~kg} / \mathrm{m}^{2}$ はシロボヤの 重量の違いであった。シロボヤとフジツボ類で重量の大 部分を占めていた。なお、主な種類は 3 種基板でほぼ同 一であり、主に 4-10月はカンザシゴカイ類、フサコケ ムシ、シロボヤおよびフジツボ類が確認された。水温の 低い時期は藻類のフクロノリが出現した。

12 ケ月基板における付着重量は石炭灰コンクリートが $18 \mathrm{~kg} / \mathrm{m}^{2}$ 、普通コンクリートが $29 \mathrm{~kg} / \mathrm{m}^{2}$ であり、6 ケ月 の結果とは逆に普通コンクリートが上回った。両者の差 は6ヶ月の場合と同様にシロボヤの付着重量の違いであっ

Table 1. The number of fouling animals per $\mathrm{m}^{2}$ on test panels submerged for one month at the pier of Nagasaki Prefectural Institute of Fisheries in Shin-Nagasaki fishing port from October, 2004, to February, 2006.

\begin{tabular}{|c|c|c|c|c|c|c|c|c|c|c|c|c|c|c|c|}
\hline Days of submersion & $10 / 14-$ & $17-$ & $14-$ & $1 / 18-$ & $2 / 18-$ & $3 / 14$ & $4 / 19-$ & $5 / 17-$ & $6 / 14-$ & $7 / 15-$ & $8 / 24-$ & $9 / 16-$ & $0 / 18-$ & $1 / 16-$ & $3-1 / 10$ \\
\hline Duration (days) & 34 & 27 & 35 & 31 & 28 & 36 & 28 & 28 & 31 & 40 & 23 & 32 & 29 & 27 & 28 \\
\hline \multicolumn{16}{|l|}{$<$ Coal-flyash concrete plate $>$} \\
\hline Polychaetes & 620 & 130 & 40 & 0 & 0 & 20 & 2,290 & 9,470 & 5,510 & 8,270 & 2,380 & 20,310 & 1,440 & 110 & 0 \\
\hline Barnacles & 70 & 0 & 0 & 0 & 0 & 0 & 270 & 1,040 & 130 & 13,090 & 360 & 1,020 & 240 & 0 & 0 \\
\hline Amphibalanus amphitrite & 0 & 0 & 0 & 0 & 0 & 0 & 0 & 110 & 130 & 7,640 & 310 & 930 & 220 & 0 & 0 \\
\hline Balanus trigonus & 70 & 0 & 0 & 0 & 0 & 0 & 220 & 930 & 0 & 5,420 & 20 & 20 & 20 & 0 & 0 \\
\hline Amphibalanus eburneus & 0 & 0 & 0 & 0 & 0 & 0 & 0 & 0 & 0 & 20 & 0 & 70 & 0 & 0 & 0 \\
\hline Megabalanus rosa & 0 & 0 & 0 & 0 & 0 & 0 & 40 & 0 & 0 & 0 & 20 & 0 & 0 & 0 & 0 \\
\hline Bryozoans & 0 & 20 & 0 & 0 & 0 & 0 & 40 & 330 & 1,250 & 580 & 530 & 580 & 160 & 0 & 0 \\
\hline Ascidians & 0 & 0 & 0 & 0 & 0 & 0 & 0 & 220 & 0 & 40 & 40 & 40 & 0 & 0 & 0 \\
\hline$<$ Ordinary concrete plate $>$ & 0 & 0 & 0 & 0 & 0 & 0 & 0 & 0 & 0 & 0 & 0 & 0 & 0 & 0 & 0 \\
\hline Polychaetes & 6,330 & 130 & 180 & 0 & 0 & 20 & 2,690 & 5,960 & 5,240 & 7,360 & 2,240 & 14,530 & 980 & 200 & 0 \\
\hline Barnacles & 210 & 0 & 0 & 0 & 0 & 0 & 290 & 870 & 870 & 21,530 & 180 & 510 & 0 & 0 & 0 \\
\hline Amphibalanus amphitrite & 20 & 0 & 0 & 0 & 0 & 0 & 0 & 160 & 780 & 7,730 & 90 & 380 & 0 & 0 & 0 \\
\hline Balanus trigonus & 190 & 0 & 0 & 0 & 0 & 0 & 270 & 710 & 40 & 13,690 & 90 & 90 & 0 & 0 & 0 \\
\hline Amphibalanus eburneus & 0 & 0 & 0 & 0 & 0 & 0 & 0 & 0 & 40 & 110 & 0 & 40 & 0 & 0 & 0 \\
\hline Megabalanus rosa & 0 & 0 & 0 & 0 & 0 & 0 & 20 & 0 & 0 & 0 & 0 & 0 & 0 & 0 & 0 \\
\hline Bryozoans & 20 & 90 & 20 & 0 & 0 & 20 & 220 & 620 & 1,040 & 1,910 & 200 & 160 & 40 & 0 & 0 \\
\hline Ascidians & 0 & 0 & 0 & 0 & 0 & 0 & 0 & 0 & 0 & 0 & 0 & 70 & 0 & 0 & 0 \\
\hline$<$ Polyvinyl chloride plate $>$ & 0 & 0 & 0 & 0 & 0 & 0 & 0 & 0 & 0 & 0 & 0 & 0 & 0 & 0 & 0 \\
\hline Polychaetes & 1,070 & 20 & 0 & 0 & 0 & 20 & 710 & 530 & 1,040 & 6,840 & 490 & 6,310 & 200 & 0 & 0 \\
\hline Barnacles & 20 & 0 & 0 & 0 & 0 & 0 & 70 & 40 & 0 & 1,160 & 0 & 0 & 0 & 0 & 0 \\
\hline Amphibalanus amphitrite & 0 & 0 & 0 & 0 & 0 & 0 & 0 & 0 & 0 & 470 & 0 & 0 & 0 & 0 & 0 \\
\hline Balanus trigonus & 20 & 0 & 0 & 0 & 0 & 0 & 40 & 20 & 0 & 690 & 0 & 0 & 0 & 0 & 0 \\
\hline Megabalanus rosa & 0 & 0 & 0 & 0 & 0 & 0 & 20 & 20 & 0 & 0 & 0 & 0 & 0 & 0 & 0 \\
\hline Bryozoans & 0 & 0 & 20 & 0 & 0 & 20 & 220 & 180 & 180 & 330 & 130 & 270 & 20 & 0 & 0 \\
\hline Ascidians & 0 & 0 & 0 & 0 & 0 & 0 & 0 & 0 & 0 & 0 & 0 & 70 & 0 & 0 & 0 \\
\hline
\end{tabular}




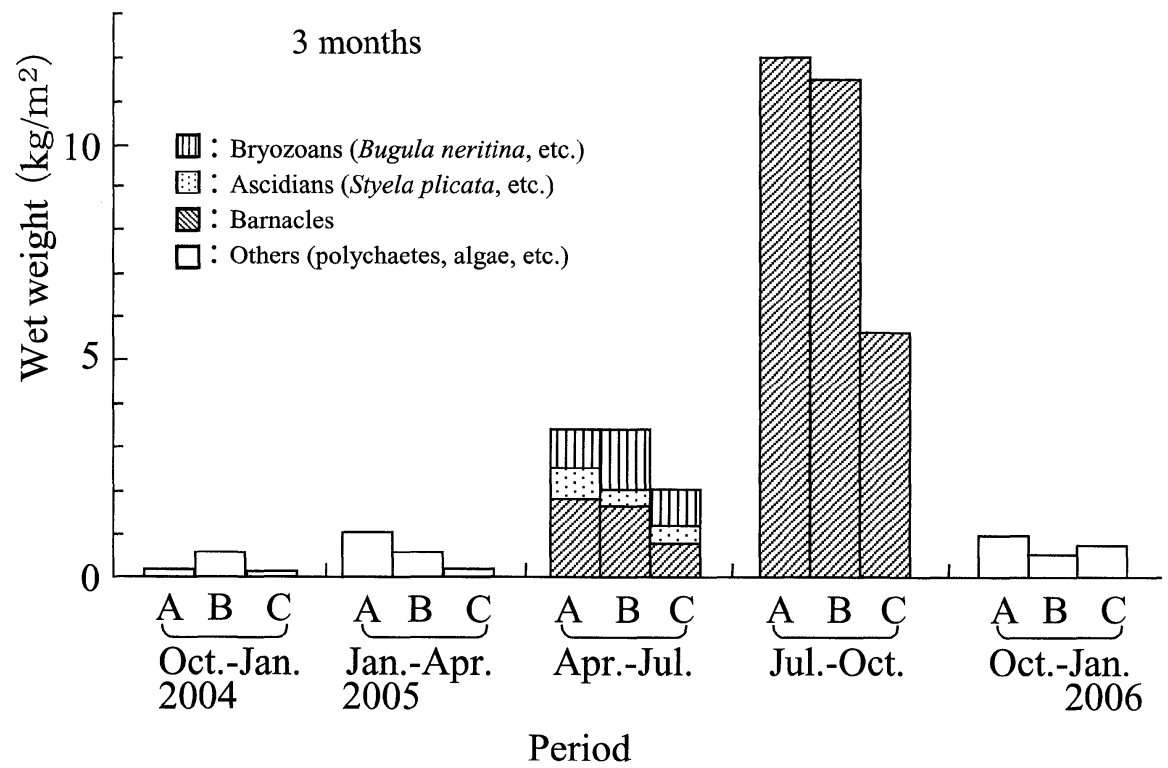

Fig. 3 Wet weight of sessile organisms on test plates submerged for three months during the period between October, 2004, and February, 2006.

A: Coal-flyash concrete plate, B: Ordinary concrete plate, C: Polyvinyl chloride plate.

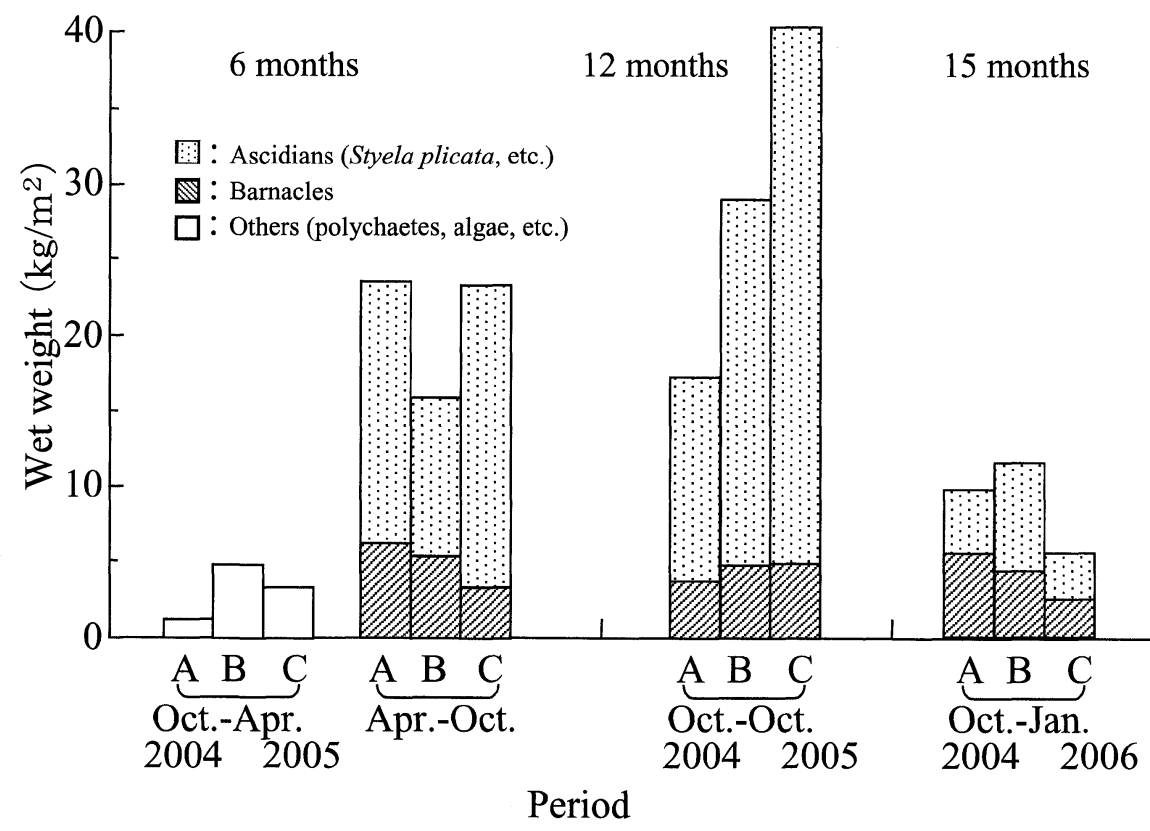

Fig. 4 Wet weight of sessile organisms on test plates submerged for six, 12, and 15 months during the period between October, 2004, and February, 2006.

A: Coal-flyash concrete plate, B: Ordinary concrete plate, C: Polyvinyl chloride plate.

た。付着生物の種類としては、先の 3 ヶ月や 6 ケ月に加 え、ムラサキイガイ (Mytilus galloprovincialis) な どの二枚貝が確認された。塩化ビニルは両コンクリート 基板に比べて重く $40 \mathrm{~kg} / \mathrm{m}^{2}$ であり、このうち大部分はシ ロボヤが占めた（Fig. 4)。

15 ケ月基板では、石炭灰コンクリートは $10 \mathrm{~kg} / \mathrm{m}^{2}$ 、普 通コンクリートは $11 \mathrm{~kg} / \mathrm{m}^{2}$ であり、両者の重量には差は みられなかった。調査は 1 月に終了したが、各々の基板
でシロボヤの萎縮個体および筋膜体等の内部が溶け出し 被囊のみとなった個体が多く認められた。その他の種類 としてはカンザシゴカイ類、コケムシ類が認められた。

\section{考 察}

石炭灰コンクリート、普通コンクリートおよび塩化ビ ニルにおける 1 ケ月垂下の付着重量（Fig. 2) について は、 2 種コンクリート基板で違いはなく、冬期の数十 $\mathrm{g}$ 
$/ \mathrm{m}^{2}$ から夏の $700 \mathrm{~g} / \mathrm{m}^{2}$ で推移した。塩化ビニル板は、 これらに比べて全体に低い值であった。塩化ビニルの付 着重量が少なかったのは、2種のコンクリート基板と比 較して表面がなめらかで生物が付着しにくいものとも考 えられる。なお、これら基板の表面粗度の測定を試みた が、石炭灰コンクリートは表面に小穴が数多く存在して いたため測定不能であった。主な出現種類（Table 1) は 3 種基板でほぼ同様であり、水温の低い時期でアオサ 類、春〜秋にカンザシゴカイ類、コケムシ類、夏にフジ ツボ類が出現した。カンザシゴカイ類は春と秋との 2 回、 フサコケムシは 5-7月に付着しており、これらの出現 時期は隣接する長崎港（北村、1993）での結果と一致す る。1 月月垂下の結果より、2 種のコンクリート板につ いては付着重量、種類に違いがないと思われる。

次に、3 ケ月垂下調査（Fig. 3) について、10-4月 の時期では全ての基板で付着重量はほぼ $1 \mathrm{~kg} / \mathrm{m}^{2}$ 以下と なり、出現種類も同様でフクロノリ、アオサ類などが占 めた。水温の上昇する $4-7$ 月では、フジツボ類、フサ コケムシ、シロボヤが付着し、石炭灰コンクリートと普 通コンクリートとは共に約 $4 \mathrm{~kg} / \mathrm{m}^{2}$ となった。 7 -10月 ではタテジマフジツボとサンカクフジツボが多くを占め、 両コンクリート基板で共に $12 \mathrm{~kg} / \mathrm{m}^{2}$ ほどとなり、違いは 認められなかった。塩化ビニルは $6 \mathrm{~kg} / \mathrm{m}^{2}$ であり、1 月垂下での付着重量の少なかったことが影響しているも のと想像される。3 月板においても、これらコンクリー 卜基板には差はないと思われる。

垂下 6 ケ月（Fig. 4）では、夏期で石炭灰コンクリー トが $23 \mathrm{~kg} / \mathrm{m}^{2}$ 、普通コンクリートが $16 \mathrm{~kg} / \mathrm{m}^{2}$ となり、 石炭灰コンクリートが $7 \mathrm{~kg} / \mathrm{m}^{2}$ 上回った。この違いはシ ロボヤの付着重量の差である。12ヶ月基板（Fig. 4) は 1 回の垂下・取り上げであるが、石炭灰コンクリートが $18 \mathrm{~kg} / \mathrm{m}^{2}$ 、普通コンクリートが $29 \mathrm{~kg} / \mathrm{m}^{2}$ であり、この違 いも同様にシロボヤの着生量の差である。出現種類は、 各基板で同様であり、フジッボ類とシロボヤが卓越して おり、シロボヤの付着数によって重量が左右されると言 える。ところで塩化ビニル板は、全調査を通して最大の $40 \mathrm{~kg} / \mathrm{m}^{2}$ を示したが、本基板は 1 - 3 ケ月垂下でみたよ うに、比較的短い垂下期間では付着重量は少ないことか ら、付着しにくいものの、一旦、付着すると剥がれにく い性質の基板と想像される。15ヶ月基板（Fig. 4）では、 3 種基板とも 12 ケ月基板と比心゙付着重量が減少している が、これは、主にシロボヤの萎縮によるものである。

以上をまとめると、付着生物の種類については、3 種 類の基板で差は小さく、カンザシゴカイ類、フジツボ類 (タテジマフジツボ、サンカクフジツボ)、およびシロボ ヤ、また冬期にはアオサなどの海藻類が認められた。付 着重量については石炭灰コンクリートと普通コンクリー
トとでは大きな違いはないと思われる。これより付着生 物の着生状況からみると、人工魚礁材料として使用する 上では、石炭灰コンクリートは普通コンクリートと同等 の効果を持つものと判断した。

なお、今回の垂下実験から得られた生物学的な知見亡 して、主に 1 ケ月垂下からは、カンザシゴカイ類の幼生 の着生時期は $6-8$ 月と 9-10月の 2 回、同じくフジッ ボ類が $7-8$ 月、コケムシ類が $5-7$ 月と推定された。 これについては既報（梶原、1964、北村、1993）と一致 しており、西日本での一般的な傾向と考えられる。シ口 ボヤについては、産卵盛期が $6-8$ 月（内田、1986）と されるが、今回の 1 ケ月垂下では確認できなかった。付 着個体が小さく（1 mm以下）肉眼では観察できなかった ものと思われる。この時期はフジツボ類の付着時期と重 なり、幼生の付着競合が存在し、この結果により優占種 が大きく異なってくると言える。また塩化ビニル板につ いては、付着しにくいものの、剥がれにくい基板と思わ れたが、表面粗度を一つの指標としてさらに検討する必 要があると思われる。

\section{謝 辞}

垂下基板の設置に際して、種々の便宜を頂きました長 崎県総合水産試験場の皆様に感謝申し上げます。

\section{引用文献}

付着生物研究会編 (1986).「付着生物研究法, 種類査定・調査 法」. 恒星社厚生閣, 東京, $156 \mathrm{pp}$.

平田 徹 (1991). 生物の相互作用と遷移.「海洋生物の付着機 構」（梶原 武監修、水産無脊椎動物研究所編）、恒星社厚 生閣、東京、pp.165-181.

梶原 武 (1964). 海産污損付着生物の生態学的研究. 長崎大学 水産学部研究報告, 16,1-138.

梶原 武 (1979). 付着動物の調査法. 付着生物研究, 1(1), 2127.

柿本 晧 (1998). 魚礁関連技術発達の経過と今後の方向, 水産 工学, 35(2), 139-144.

北村 等 (1993). 長崎湾内の松ヶ枝と長浜における付着生物. 長崎大学水産学部研究報告, 74-75, 25-29.

(社)マリノフォーラム21 (1988). 新素材に関する開発研究報 告書, pp.56-64.

（社）マリノフォーラム21（1989）。石炭灰コンクリート設計・ 製作マニュアル, pp.1-3.

（社）マリノフォーラム21（1997）。平成8年度マウンド漁場造成 システムの開発に関する報告書, pp.1-15.

(社) 全国沿岸漁業振興開発協会 (2000). 沿岸漁場整備開発事 業人工魚礁漁場造成計画指針, 平成12年度版, $226 \mathrm{pp}$.

水産庁振興部開発課長通達 (1983). 沿岸漁場整備開発事業の 魚礁設置事業に係る新規構造物の取り扱いについて

内田 亨 (1986). 半索動物・原索動物. 「動物系統分類学, 第8 巻下」, 中山書店, 東京, pp.140-143. 